\title{
HUBUNGAN PERHATIAN ORANG TUA DENGAN MINAT BELAJAR SISWA SMA SWASTA ABDI NEGARA BINJAI
}

\author{
Prina Yelly \\ Sekolah Tinggi Keguruan dan Ilmu Pendidikan Budidaya \\ prinayelly@ymail.com
}

\begin{abstract}
ABSTRAK
Penelitian ini untuk mengetahui Hubungan Perhatian Orang Tua dengan Minat Belajar Bahasa Indonesia Siswa SMA Swasta Abdi Negara Binjai Tahun Pelajaran 2016/2017. Penelitian ini dilaksanaskan di SMA Swasta Abdi Negara Binjai. Populasi dalam penelitian ini adalah siswa kelas XI dengan banyaknya 36 orang siswa. Dalam penelitian ini sampel dari keseluruhan populasi, yaitu 36 orang siswa. Instrumen yang digunakan berupa angket yang terdiri dari 20 soal tentang perhatian orang tua dan 20 soal tentang,minat belajar. Setelah data diperoleh kemudian dianalisis dengan menggunakan korelasi product moment, hasil penelitian ini menunjukkan bahwa $r_{\text {hitung }}$ lebih besar dari $\mathrm{r}_{\text {tabel }}$ atau $\mathrm{r}_{\text {hitung }}>\mathrm{r}_{\text {tabel }}(0,352>$ 0,296) berarti ada Hubungan Perhatian Orang Tua Dengan Minat Belajar Bahasa Indonesia Siswa Kelas XI SMA Swasta Abdi Negara Binjai Tahun Pelajaran 2016/2017.

Kata Kunci : Perhatian Orang Tua, Minat Belajar

\section{Pendahuluan}

Proses pendidikan dapat terjadi dalam banyak situasi sosial yang menjadi ruang lingkup kehidupan manusia. Secara garis besar proses pendidikan dapat terjadi dalam tiga lingkungan pendidikan yang terkenal dengan sebutan: Tri Logi Pendidikan, yaitu Pendidikan dalam Keluarga (Pendidikan Informal), Pendidikan di Sekolah (Pendidikan Formal), dan Pendidikan dalam Masyarakat (Pendidikan Non-Formal).

Pendidikan dalam keluarga merupakan pendidikan kodrati. Apalagi setelah anak lahir, pengenalan di antara orang tua dan anak-anaknya yang diliputi rasa cinta kasih, ketentraman dan kedamaian. Anak-anak akan berkembang ke arah kedewasaan dengan wajar dalam lingkungan keluarga segala sikap dan tingkah laku kedua orang tuanya sangat berpengaruh terhadap perkembangan anak.
\end{abstract}


Orang tua (ayah dan ibu) merupakan pendidik dalam kehidupan yang nyata dan pertama sehingga sikap dan tingkah laku orang tua akan diamati oleh anak baik disengaja maupun tidak disengaja sebagai pengalaman bagi anak yang akan mempengaruhi pendidikan selanjutnya.

Dalam proses pembelajaran di sekolah ada sebagian anak yang kurang sungguhsunggguh atau kurang minat dalam belajar, dia sering terlambat, tidak aktif mengikuti pelajaran, suka membuat ribut kelas, sering tidak mengerjakan tugas rumah (PR) seolah-olah mereka ingin diperhatikan oleh orang lain.

Anak yang berperilaku demikian tersebut biasanya mempunyai permasalahan dalam keluarganya biasanya karena orang tuanya terlalu sibuk dengan pekerjaannya. Salah satunya ibu yang bekerja sebagai tenaga kerja di luar negeri, atau karena dalam keluarganya tersebut ada permasalahan yang menyebabkan kurang harmonisnya hubungan antar anggota keluarga, terutama antara anak dengan orang tuanya.

Keterkaitan antara belajar dan hasil belajar bukan hanya tergantung pada kepintaran saja, tetapi sikap, minat belajar siswa dan kebiasaan belajar serta faktor yang berasal dari luar siswa juga mempunyai pengaruh dalam menentukan keberhasilan belajar siswa. Peran orang tua adalah salah satu faktor yang berasal dari luar individu yang memberikan pengaruh besar bagi pendidikan anak. Orang tua memiliki tanggung jawab utama atas perawatan dan perlindungan anak sejak bayi sampai remaja dan mandiri.

Lingkungan keluarga (orang tua) merupakan landasan yang kuat untuk mencapai kedewasaan anak. Tugas dan tanggung jawab orang tua terhadap pendidikan anak lebih bersifat pembentukan watak, budi pekerti, latihan keterampilan, dan pendidikan kesosialan. Orang tua memiliki peranan dalam mempersiapkan anak-anak untuk mencapai masa depan terutama dalam penanaman sikap dan perilaku serta nilai hidup, pengembangan bakat dan minat serta pembinaan bakat dan kepribadian.

Pendidikan yang diterima dari orang tua inilah yang nantinya akan digunakan oleh anak sebagai dasar untuk mengikuti pendidikan selanjutnya di sekolah. Perhatian orang tua terhadap anak diwujudkan pula dalam penyediaan sarana dan prasarana belajar agar anak lebih termotivasi dalam melaksanakan tugas ataupun kewajiban belajar maupun keterampilan atau bakat yang akan anak kembangkan.

Akibat kesulitan ekonomi yang melanda bangsa Indonesia, orang tua cenderung meninggalkan kewajibanya sebagai orang tua terhadap anak. Perhatian, pengawasan, dan bimbingan yang seharusnya dibutuhkan anak dalam belajar sering terabaikan karena lebih 
mementingkan kebutuhan ekonomi sehingga mengakibatkan prestasi dan perilaku belajar yang kurang baik pada siswa.

Hal itu dapat terlihat dari bagaimana sikap dan perilaku siswa di sekolah, di mana pelanggran peraturan sekolah, keterlambatan, ketidak disiplinan siswa dalam belajar dan prestasi yang dicapai siswa dalam belajar yang tidak sesuai dengan apa yang diharapkan oleh guru, orang tua maupun sekolah.

Selain itu, orang tua merupakan salah satu faktor yang berasal dari dalam diri siswa memberikan pengaruh pada prestasi belajar. Seseorang yang mempunyai minat dalam belajar akan berusaha mencurahkan segenap kemampuanya untuk menguasai ilmu yang dipelajarinya agar mencapai hasil belajar yang optimal. Suatu kegiatan yang di dasari pada minat akan memberikan perasaan senang pada orang tersebut dalam melakukan kegiatan, sehingga akan tercapai hasil yang optimal.

Dari uraian di atas, maka penelitian ini akan mengungkap tentang " Hubungan Perhatian Orang Tua Dengan Minat Belajar Bahasa Indonesia Siswa Kelas XI SMA Swasta Abdi Negara Binjai Tahun Pelajaran 2016/2017.”

\section{Landasan Teori}

\section{A. Pengertian Perhatian Orang Tua}

Perhatian menurut Sumadi Suryabrata adalah "pemusatan tenaga psikis tertuju kepada suatu objek”. ${ }^{1}$ Sedangkan Bimo Walgito mengemukakan bahwa perhatian merupakan "pemusatan atau konsentrasidari seluruh aktifitas individu yang ditunjukkan kepada sesuatu atau sekumpulan obyek". ${ }^{2}$ Kemudian Kartini Kartono menyatakan bahwa "perhatian itu merupakan reaksi umum dari organisme dan kesadaran yang menyebabkan bertambahnya aktivitas, daya konsentrasi, dan pembatasan kesadaran terhadap satu obyek”. ${ }^{3}$

Dari beberapa pengertian perhatian menurut para pakar tersebut,maka, dapat disimpulkan bahwa perhatian adalah pemusatan atau kesadaran jiwa yang diarahkan kepada sesuatu obyek tertentu yang memberikan rangsangan kepada individu, sehingga ia hanya mempedulikan obyek yang merangsang itu. Maka, perhatian orang tua dapat diartikan sebagai kesadaran jiwa orang tua untuk memperdulikan anaknya, terutama dalam hal memberikan dan memenuhi kebutuhan anaknya, baik dalam segi emosional maupun material.

\section{B. Bentuk Perhatian Orang Tua Terhadap Minat Belajar Anak}

1 Sumadi Suryabrata, Psikologi Pendidikan, (Jakarta: Raja Grafindo Persada, 1993), hlm. 14.

2 Bimo Walgito, Pengantar Psikologi Umum, (Yogyakarta: Andi Offset, 1990), hlm. 56.

3 Kartini Kartono, Psikologi Umum, (Bandung : Mandar Maju, 1996), Cet. III, hlm. 11 
Perhatian orang tua, terutama dalam hal pendidikan anak sangatlah diperlukan. Terlebih lagi yang harus difokuskan adalah perhatian orang tua terhadap aktivitas belajar yang dilakukan anak sehari-hari dalam kapasitasnya sebagai pelajar dan penuntut ilmu, yang akan diproyeksikan kelak sebagai pemimpin masa depan.

Bentuk perhatian orang tua terhadap belajar anak dapat berupa pemberian bimbingan dan nasihat, pengawasan terhadap belajar anak, pemberian motivasi dan penghargaan serta pemenuhan kebutuhan belajar anak.

a. Pemberian Bimbingan dan Nasihat

1) Pemberian Bimbingan Belajar

2) Memberikan Nasihat

b. Pengawasan Terhadap Belajar

c. Pemberian Motivasi dan Penghargaan

d. Pemenuhan Kebutuhan Belajar

\section{Teori Tentang Minat Belajar}

\section{a. Pengertian Minat Belajar}

Menurut Muhibin Syah "minat adalah kecenderungan dan kegairahan yang tinggi atau keinginan yang besar terhadap sesuatu”. ${ }^{4}$ Sementara itu Slameto mengatakan bahwa "minat adalah suatu rasa lebih suka dan rasa ketertarikan pada suatu hal atau aktivitas, tanpa ada yang menyuruh”. ${ }^{5}$ Tingkah laku siswa ketika mengikuti proses pembelajaran dapat mengindikasikan akan ketertarikan siswa tersebut terhadap pelajaran itu atau sebaliknya. Ketertarikan siswa inilah yang merupakan salah satu tanda-tanda minat.

Berdasarkan pengertian tersebut dapat disimpulkan bahwa minat akan timbul apabila mendapatkan rangsangan dari luar. Adapun kecenderungan untuk merasa tertarik pada suatu bidang bersifat menetap dan merasakan perasaan yang senang apabila siswa terlibat aktif di dalamnya. Meskipun perasaan senang ini timbul dari lingkungan atau berasal dari objek yang menarik.

Menurut Slameto "belajar ialah suatu proses usaha yang dilakukan seseorang untuk memperoleh suatu perubahan tingkah laku yang baru secara keseluruhan, sebagai hasil pengalamannya sendiri dalam interaksi dengan lingkungannya”. ${ }^{6}$ Sedangkan menurut Suyono dan Hariyanto "belajar adalah suatu aktivitas atau suatu proses untuk memperoleh pengetahuan, peningkatan keterampilan, memperbaiki prilaku, sikap, dan mengkokohkan

4 Muhibbin Syah. Psikologi Belajar. (Jakarta: Rajawali. Perss.2011), hlm. 152

5 Slameto. Belajar \& Faktor-Faktor Yang Mempengaruhinya, (jakarta, Rineka Cipta,2010), ～hlm. 180 6 Ibid, hlm. 2 
kepribadian”.7 Selain itu, Gagne dalam Suprijono menyatakan bahwa "belajar adalah perubahan disposisi atau kemampuan yang dicapai seseorang melalui aktivitas”. ${ }^{8}$

Berdasarkan pembahasan di atas, maka dapat disimpulkan bahwa minat belajar adalah rasa tertarik atau kecenderungan melakukan suatu kegiatan untuk memperoleh pengetahuan atau perubahan prilaku sebagai hasil pengalamannya sendiri dalam interaksi dengan lingkungannya.

Dengan demikian, apabila seorang guru ingin berhasil dalam melakukan kegiatan pembelajaran harus dapat memberikan rangsangan kepada siswa agar berminat dalam mengikuti proses kegiatan pembelajaran tersebut. Apabila siswa sudah merasa berminat mengikuti pelajaran, maka siswa akan menangkap dan mengerti dengan mudah apa yang di sampaikan oleh guru, begitu juga sebaliknya apabila siswa merasakan tidak berminat dalam melakukan proses kegiatan pembelajaran ia akan merasa tersiksa, jenuh, dan bosan dalam mengikuti pelajaran tersebut.

\section{b. Aspek Teori Minat Belajar}

Menurut Lilawati dalam Ida Zusnani mengartikan minat adalah suatu perhatian yang kuat dan mendalam disertai dengan perasaan senang terhadap suatu kegiatan sehingga mengarahkan anak untuk melakukan kegiatan tersebut dengan kemauan sendiri. ${ }^{9}$ Hurlock mengatakan bahwa minat merupakan hasil dari pengalaman atau proses belajar. Hurlock mengemukakan bahwa minat memiliki dua aspek, yaitu:

1) Aspek kognitif

2) Aspek afektif

\section{c. Indikator Minat Belajar}

Slameto menyatakan bahwa "minat adalah suatu rasa lebih suka dan rasa ketertarikan pada suatu hal atau aktivitas, tanpa ada yang menyuruh”. ${ }^{10}$ Minat pada dasarnya adalah penerimaan akan suatu hubungan antara diri sendiri dengan sesuatu di luar diri. Semakin kuat atau dekat hubungan tersebut semakin besar minat. Suatu minat dapat diekspresikan melalui suatu pernyataan yang menunjukkan bahwa siswa lebih menyukai suatu hal dari pada hal lainnya, dapat pula dimanifestasikan melalui partisipasi dalam suatu aktivitas. Siswa yang memiliki minat terhadap subjek tertentu cenderung untuk memberikan perhatian yang lebih besar terhadap subjek tertentu.

7 Suyono dan Hariyanto, Belajar dan Pembelajaran: Teori dan Konsep Dasar. (Bandung: PT Remaja Rosdakarya, 2012), hlm. 9

8 Agus Suprijono. Cooperative Learning Teori dan Aplikasi Paikem. (Yogyakarta : Pustaka Pelajar ,2013), hlm.

9 Ida Zusnani. Pendidikan Kepribadian Siswa SD-SMP. (Jakarta: Platinum, 2013), hlm. 79

10 Slameto. Belajar \& Faktor-Faktor Yang Mempengaruhinya, (jakarta, Rineka Cipta,2010), hlm. 180 
Berdasarkan definisi tersebut, maka dapat disimpulkan indikator minat belajar adalah rasa suka/senang dalam aktivitas belajar, rasa ketertarikan untuk belajar, adanya kesadaran untuk belajar tanpa disuruh, berpartisipasi dalam aktivitas belajar, memberikan perhatian yang besar dalam belajar. Ada beberapa indikator yang mempengaruhi minat belajar siswa, antara lain:

1) Rasa tertarik

2) Perasaan senang

3) Perhatian

4) Partisipasi

5) Keinginan/kesadaran.

\section{d. Faktor-faktor yang Mempengaruhi Minat Belajar}

Salah satu pendorong dalam keberhasilan belajar adalah minat yang tinggi. "Minat itu tidak muncul dengan sendirinya akan tetapi banyak faktor yang dapat mempengaruhi munculnya minat. ${ }^{11}$ Ada beberapa faktor yang dapat mempengaruhi minat belajar siswa antara lain: (1) Motivasi, (2) Belajar, (3) Bahan Pelajaran dan Sikap Guru, (4) Keluarga, (5) Teman Pergaulan, (6) Lingkungan, (7) Cita-cita, (8) Bakat, (9) Hobi, (10) Media Massa, (11) Fasilitas”. ${ }^{12}$ Faktor-faktor tersebut dapat dijelaskan sebagai berikut:

\section{Pengertian Hasil Belajar}

Para ahli belajar modern menyatakan bahwa hasil belajar pada dasarnya adalah suatu kemampuan yang berupa keterampilan dan perilaku baru sebagai akibat dari latihan dan pengalaman yang diperoleh. Dalam hal ini, Indra menyatakan bahwa "hasil belajar adalah kemampuan-kemampuan yang dimiliki siswa setelah ia menerima pengalaman belajarnya”.13

Menurut Nana Sudjana dalam Kunandar hasil belajar adalah suatu akibat dari proses belajar dengan menggunakan alat pengukuran, yaitu berupa tes yang disusun secara terencana, baik tes tertulis, tes lisan maupun tes perbuatan. ${ }^{14}$ Menurut Hakim dalam Silalahi ada beberapa faktor yang mempengaruhi keberhasilan belajar, yaitu faktor internal dan eksternal. ${ }^{15}$

1) Faktor Internal

11 Katampunge, Meiske. Faktor yang Mempengaruhi Minat Belajar ( Jakarta ,Rineka Cipta ,2013), hlm. 70 12 Ibid, Hlm. 70

13 Indra.. Hasil Belajar. http://indramunawar.blogspot.com/2009/06/hasil-belajar-pengertian-dandefinisi.html

14 Nana Sudjana. Penilaian Hasil Proses Belajar Mengajar. (Bandung: PT Remaja Rosdakarya, 2008), hlm. 276

15 Karlinawati Silalahi. Keluarga Indonesia Aspek dan Dinamika Zaman. (Jakarta: Raja Grafindo Persada, 2010), hlm. 170-172 
Faktor internal meliputi dua hal, yaitu faktor jasmani dan faktor psikis. Faktor jasmani merupakan kesehatan dan kesiapan fisik seseorang untuk belajar. Faktor psikis meliputi inteligensi, konsentrasi, kepribadian, dan gaya belajar.

2) Faktor Eksternal

Faktor eksternal meliputi beberapa hal, yaitu lingkungan keluarga, lingkungan sekolah, lingkungan masyarakat, dan waktu.

Menurut Suprijono Hasil belajar adalah perubahan prilaku secara keseluruhan bukan hanya salah satu aspek potensi kemanusiaan saja. Artinya, hasil pembelajaran yang dikategorisasi oleh para pakar pendidikan sebagaimana tersebut di atas tidak terlihat secara fragmentaris atau terpisah, melainkan komprehensif. ${ }^{16}$

\section{Hakikat Bahasa Indonesia}

\section{Pengertian Bahasa}

Harimurti memberikan batasan bahasa sebagai sistem lambang arbitrer yang dipergunakan suatu masyarakat untuk bekerja sama, berinteraksi, dan mengidentifikasikan diri. Batasan ini merupakan batasan yang lazim diungkapkan, baik oleh para ilmuwan bahasa maupun para ilmuwan yang lainnya.

Dua ilmuwan Barat, Bloch dan Trager, mendefinisikan bahasa sebagai suatu "sistem simbol-simbol bunyi yang arbriter yang dipergunakan oleh suatu kelompok sosial sebagai alat untuk berkomunikasi (Language is a system of arbitrer vocal symbol by means of which a social group cooperates).

Bahasa dibentuk oleh kaidah aturan serta pola yang tidak boleh dilanggar agar tidak menyebabkan gangguan pada komunikasi yang terjadi. Kaidah aturan , dan pola-pola yang dibentuk mencakup tata bunyi, tata bentuk dan tata kalimat. Agar komunikasi yang dilakukan berjalan lancar dengan baik, penerima dan pengirim bahasa harus harus menguasai bahasanya.

Bahasa juga digunakan untuk mengetahui ciri bahasa yang dipakai oleh masyarakat yang ada di Indonesia. Dengan adanya bahasa, masyarakat dapat berkomunikasi sesuai dengan bahasa yang dimilkinya dan segala permasalahan dapat dipecahkan dengan adanya alat komunikasi atau bahasa.

2. Fungsi Bahasa Indonesia

Secara umum, fungsi bahasa ada tiga, yaitu alat komunikasi, alat ekspresi, dan alat berpikir. Ketika seseorang menggunakan bahasa, ada sesuatu yang ingin disampaikan berupa informasi. Informasi tersebut bisa ditransformasi dua arah arah seperti pada dialog, dan ada

16 Agus Suprijono. Cooperative Learning. (Yogyakarta: Pustaka Pelajar, 2013),hlm. 5 
juga disamapaikan searah seperti pada pidato. Ekspresi seseorang ketika menyatakan senang atau susah paling lengkap dinyatakan dengan bahasa, tidak dapat hanya tersenyum atau menangis.

Secara khusus, bahasa Indonesia berfungsi sebagai alat komunikasi antara anggota masyarakat Indonesia. Fungsi tersebut digunakan dalam berbagai lingkungan, tingkatan, dan kepentingan yang beraneka ragam. Hal ini, sesuai dengan prinsip sosiologis yang menyatakan bahwa manusia tidak dapat hidup seorang diri. Dalam memenuhi kebutuhan hidupnya, manusia pasti memerlukan orang lain. Mereka pun berkomunikasi dalam berbagai lingkungan di tempat mereka berada, seperti antar anggota keluarga, antar masyarakat, antar teman sejawat, antarilmuwan, dan sebagainya. ${ }^{17}$

Bahasa menunjukkan perbedaan antara satu penutur dengan penutur lainnya, tetapi masing-masing tetap mengikat kelompok penuturnya dalam satu kesatuan sehingga bahasa memungkinkan tiap individu menyesuaikan dirinya dengan adat istiadat dan kebiasaan masyarakat bahasa tersebut. Bahasa juga melambangkan pikiran atau gagasan tertentu, dan juga melambangkan perasaan, kemauan bahkan dan melambangkan tingkah laku seseorang.

Kedudukan bahasa mempunyai dua kedudukan, yaitu kedudukan sebagai bahasa nasional dan kedudukan sebagai bahasa negara. Bahasa nasional mulai berlaku sejak tanggal 28 Oktober 1928 yang biasa diperingati Hari Sumpah Pemuda. Bahasa negara mulai berlaku sejak tanggal 18 Agustus 1945 dengan adanya Pancasila dan UUD 1945 pasal 36 yang isinya tentang Bahasa Indonesia.

\section{Hubungan Perhatian Orang Tua terhadap Minat Belajar Bahasa Indonesia}

Pendidikan adalah tanggung jawab bersama antara keluarga, masyarakat dan pemerintah. Dengan demikian, pendidikan anak tidak semata tanggung jawab sekolah, tetapi bersama antara orang tua, sekolah dan masyarakat. Sesungguhnya orang tua merupakan penanggung jawab utama pendidikan anak. Dalam pengertian ini, keberhasilan pendidikan anak di sekolah bukan hanya merupakan hasil perjuangan guru dan anak sebagai peserta didik. Tetapi, keberpihakan orang tua yang memberikan dukungan berupa perhatian, dorongan dan pengawasan kepada anaknya ikut memberikan andil.

Perhatian orang tua pada aktivitas belajar anak dengan segala yang berhubungan dengannya, dapat memberikan motivasi berprestasi yang tinggi dan memunculkan simpati anak kepada orang tua yang pada akhirnya dapat menumbuhkan kepercayaan pada diri anak. Perhatian orang tua sesungguhnya merupakan investasi kepada anak dalam meningkatkan

17 Ramlan A. Gani dan Mahmudah Fitriyah Z.A., Displin Berbahasa Indonesia, (Jakarta: FITK PRESS, 2010), hlm 2 
aktivitas belajar, dan membantu memaksimalkan perkembangan kepribadian serta prestasi belajar. Senada dengan hal tersebut, Pramuji Wibowo menyatakan sebagai berikut:

Motivasi ekstrinsik yang paling utama adalah dari orang tua atau keluarga. Hal ini dikarenakan semenjak kecil anak bersosialisasi, menerima pendidikan (pendidikan informal) pertama kalinya adalah di dalam keluarga, dan pendidikan yang diperoleh dalam keluarga ini merupakan pendidikan yang terpenting atau utama terhadap perkembangan pribadi anak. Belajar sebagai proses interaksi untuk mencapai tujuan akan lebih efektif, bila ditunjang dengan motivasi yang tinggi, baik yang berupa intrinsik maupun ekstrinsik, dan orang tua adalah hal yang signifikan dalam membangkitkan motivasi seseorang. ${ }^{18}$

Perhatian yang cukup dan perlakukan orang tua yang bijaksana terhadap anak, akan berdampak pada kemampuan pengembangan potensi diri anak yang melahirkan motivasi belajar yang tinggi dan kemampuan berkonsentrasi dalam aktivitas belajarnya yang akhirnya berpengaruh kepada pencapaian prestasi yang maksimal.

\section{B. Kerangka Konseptual}

Kepedulian orang tua kepada anak memiliki peranan penting dalam menanamkan nilai- nilai kehidupan, baik yang berupa perhatian ataupun pembinaan dalam segala bidang. Pendidikan keluarga juga memiliki arti penting bagi pertumbuhan dan perkembangan anak, orang tua memiliki peran yang utama sebagai peletak dasar bagi kesiapan anak-anaknya agar memiliki perilaku yang baik sehingga anak mampu berprestasi dalam belajar dan dalam kehidupannya. Karena belajar merupakan kebutuhan seumur hidup atau sering kita sebut” Long Live Educatian”.

Perhatian orang tua bukan satu-satunya faktor yang dapat mempengaruhi prestasi belajar siswa, faktor yang berpengaruh terhadap jalannya pendidikan anak salah satunya adalah minat belajar. Dengan minat belajar yang baik diharapkan siswa mampu memperoleh hasil belajar yang memuaskan.

\section{METODE PENELITIAN}

Penelitian ini dilaksanakan di SMA Abdi Negara Binjai, yang beralamat di jalan T. Alamat Hamzah, No. 682, Binjai utara, Binjai. Provinsi Sumatera Utara. Adapun lokasi penelitian tersebut dipilih karena tersedianya data yang berhubungan dengan masalah penelitian dan berguna untuk mendukung tercapainya tujuan penelitian. Penelitian ini dilaksanakan pada semester ganjil tahun pelajaran 2016/2017.

Sesuai dengan permasalahan dan objek yang dikaji, Penelitian korelasi atau korelasional adalah suatu penelitian untuk mengetahui hubungan dan tingkat hubungan antara

18 Pramuji Wibowo,"Pengaruh Motivasi Terhadap Efektivitas Belajar”, http://pramujiwibowo.wordpress.com. 13 Maret 2007. 
dua variabel atau lebih tanpa ada upaya untuk mempengaruhi variabel tersebut sehingga tidak terdapat manipulasi variabel ${ }^{19}$.

Adanya hubungan dan tingkat variabel ini penting karena dengan mengetahui tingkat hubungan yang ada, peneliti akan dapat mengembangkannya sesuai dengan tujuan penelitian. Jenis penelitian ini biasanya melibatkan ukuran statistik/tingkat hubungan yang disebut dengan korelasi ${ }^{20}$. Penelitian korelasional menggunakan instrumen untuk menentukan apakah, dan untuk tingkat apa, terdapat hubungan antara dua variabel atau lebih yang dapat dikuantitatifkan

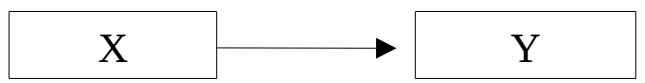

Keterangan :

$\mathrm{X}=$ Tingkat Perhatian Orang Tua Siswa kelas XI SMA Swasta Abdi Negara Binjai.

Y= Tingkat Minat Belajar siswa kelas XI SMA Swasta Abdi Negara Binjai

Desain sederhana ini menunjukkan hubungan antara satu variabel bebas (independen variabel) yang diberi simbol (X) dengan satu variabel terikat (dependen variabel) yang diberi simbol (Y).

Jadi, populasi berhubungan dengan data bukan manusianya. Populasi dalam penelitian ini adalah seluruh siswa kelas XI SMA Swasta Abdi Negara Binjai Tahun Pelajaran 2016/2017 yang berjumlah 36 siswa. Adapun sampel yang diambil adalah keseluruhan siswa yang terdapat dalam satu kelas VII yang berjumlah 36 orang siswa.

\section{HASIL PENELITIAN DAN PEMBAHASAN}

Penelitian terhadap masalah Perhatian Orang Tua Dengan Minat Belajar Bahasa Indonesia Siswa Kelas XI SMA Swasta Abdi Negara Binjai dilakukan terhadap 36 orang siswa yang dibuat dalam sebuah angket. Data yang diperoleh akan dianalisis dengan menggunakan tabulasi. Jenis tabel yang digunakan adalah tabel frekuensi dan persentase. Berdasarkan yang diperoleh skor frekuensi terendah 45 dan skor tertinggi 60, mean sebesar 54,43, median 54,91,modus sebesar 55,45 standar deviasi terendah 3,84.

Hasil perhitungan $L_{h i t u n g}$ kemudian dicari harga tertinggi yang disebut dengan lo ini dikonsultasikan dengan $L_{\text {tabel }}$ dengan taraf signifikan $\alpha^{\alpha}=0,05$ didapat, maka dapat disimpulkan bahwa data variabel $\mathrm{X}$ berdistribusi normal. Variabel $\mathrm{x}$ diperoleh $\mathrm{Lo}=0,106$

\footnotetext{
19 Faenkel dan Wallen, How To Design And Evaluate Research Education,( New York; Mc Graw- Hill Companies,Inc,2008) hlm 328

20 AR, Syamsudin. dan Vismaia S. Damaianti. Metode Penelitian Pendidikan. (Bandung: PT. Remaja Rosdakarya.2009), hlm.025
} 
dengan dk 36 pada $a=0,05 \mathrm{l}_{\text {tabel }}=0,147$ sehingga lo $0,144<0,147$. Kapasitasnya variabel $\mathrm{X}$ normal dan variabel Y diperoleh lo=0,121dan DK 36 pada $a=0.05$ sehingga $\mathrm{Lo}=0,106<$ 0,147 kapasitasnya variabel Y berdistribusi normal.

Berdasarkan prestasi tersebut, maka harga $t_{\text {hitung }}$ lebih besar dari pada $t_{\text {tabel, }}$ atau 5,187 > 2,750. Sehingga $H_{o}$ ditolak dan Ha diterima, artinya ada hubungan yang positif dan signifikan antara hubungan perhatian orang tua dengan minat belajar bahasa Indonesia Siswa Kelas XI SMA Swasta Abdi Negara Binjai Tahun Pelajaran 2016/2017.

Dikarenakan $r_{\text {hitung }}$ berada didaerah penolakan ho pada arah kanan maka ha diterima. dengan demikian, ada hubungan antara hubungan perhatian orang tua dengan minat belajar bahasa Indonesia Siswa Kelas XI SMA Swasta Abdi Negara Binjai Tahun Pelajaran 2016/2017.

\section{Kesimpulan}

Beberapa kesimpulan penelitian ini menjawab dari perumusan masalah, yaitu berdasarkan pendapat siswa pada sebuah angket menunjukkan bahwa perhatian orang tua, sebagian besar siswa beranggapan sudah cukup baik. Minat belajar siswa pada mata pelajaran bahasa Indonesia menunjukkan prestasi belajar pada bidang studi bahasa Indonesia secara umum sudah baik, karena nilai tertinggi 85 dan nilai terendah 65. Uji statistika koefisien Korelasi Pearson (r) menunjukkan bahwa persepsi siswa mengenai perhatian orang tua dengan minat belajar bahasa Indonesia terdapat hubungan positif dan signifikan dengan menggunakan uji t pada taraf siginifikan $\alpha=0,05$.

Dengan kata lain semakin baik perhatian orang tua dalam proses pembelajaran maka semakin tinggi pula minat belajar siswa pada mata pelajaran bahasa Indonesia di SMA Swasta Abdi Negara Binjai , sebaliknya semakin tidak baik perhatian orang tua dalam proses pembelajaran, maka semakin rendah pula minat belajar siswa pada mata pelajaran bahasa Indonesia di SMA Swasta Abdi Negara Binjai Tahun Pelajaran 2016/2017.

\section{DAFTAR PUSTAKA}

Arifin dan Kartikawati Etty. 1998. Materi Pokok Bimbingan dan Konseling. Jakarta: Ditjen Pembinaan Kelembagaan Agama Islam, Departemen Agama.

Kartono, Kartini. 1996. Psikologi Umum. Bandung: Mandar Maju. Katampunge, Meiske. 2013. Faktor yang Mempengaruhi Minat Belajar Jakarta,Rineka Cipta. Slameto. 2010.Belajar dan Faktor - faktor Yang Mempengaruhinya.Jakarta : Rineka Cipta. Syah Muhibbin. 2011. Psikologi Belajar. Jakarta: Rajawali. Perss. 
Suyono dan Hariyanto. 2012. Belajar dan Pembelajaran: Teori dan Konsep Dasar. Bandung: PT Remaja Rosdakarya.

Suryabrata Sumadi. 1993. Psikologi Pendidikan, Jakarta: Raja Grafindo Persada, Sugiyono. 2012. Metode Penelitian Pendidikan. Bandung: Alfabeta.

Suprijono, Agus. 2013. Cooperative Learning Teori dan Aplikasi Paikem. Yogyakarta: Pustaka Pelajar, Walgito Bimo. 1990. Pengantar Psikologi Umum, Yogyakarta: Andi Offset. Zusnani, Ida. 2013. Pendidikan Kepribadian Siswa SD-SMP. Jakarta: Platinum. 